\title{
Influence of tree species, tree diameter and soil types on wood density and its radial variation in a mid-altitude rainforest in Madagascar
}

\author{
Tahiana Ramananantoandro $^{1}$ (D) Miora F. Ramanakoto ${ }^{1}$ - Gabrielle L. Rajoelison ${ }^{1}$. \\ Jean C. Randriamboavonjy ${ }^{1}$. Herimanitra P. Rafidimanantsoa ${ }^{1}$
}

Received: 27 April 2015 / Accepted: 9 August 2016 /Published online: 15 September 2016

(C) INRA and Springer-Verlag France 2016

\begin{abstract}
- Key message In a tropical rainforest of Madagascar, tree species differed in average wood density depending on their light requirements and on the soil type. Tree diameter had no effect. None of these factors influenced the variation of density related to the distance to the pith.

- Context Wood density (WD) is an important wood property as it correlates with several functional tree traits and mechanical wood properties. Furthermore, wood density is often used in forest biomass and carbon stock estimates. The variation in wood density depends on a range of intrinsic or environmental factors.

- Aims This study investigated the effect of species, tree diameter, soil types and the distance from the pith on wood density in native hardwood species from a natural, midelevation rainforest in Madagascar.
\end{abstract}

Handling Editor: Jean-Michel Leban

Contribution of the co-authors

Tahiana Ramananantoandro: designed the study, supervised the work, run the data analysis, discussed the results and wrote the paper

Miora F. Ramanakoto: collected wood cores in the forest, carried out density measurements, run the data analysis, discussed the results and wrote the paper

Gabrielle L. Rajoelison: helped in defining the light requirements of the different species and discussed the results

Jean Chrysostome Randriamboavonjy: helped in soil type definition and discussed the results

Herimanitra P. Rafidimanantsoa: collected wood cores in the forest, carried out density measurements and discussed the results

Tahiana Ramananantoandro ramananantoandro@gmail.com

1 Département des Eaux et Forêts, Ecole Supérieure des Sciences Agronomiques, Université d'Antananarivo, BP 175, 101 Antananarivo, Madagascar
- Methods We extracted pith-to-bark core samples from the trunk of 204 trees from 23 species. Each wood core was sectioned into $1 \mathrm{~cm}$-long segments on which measures of volume and weight were performed. Within-tree and between-tree variations of wood density were analysed.

- Results Average wood density was higher on shade-tolerant than on light-demanding species. It was higher on poor ferralitic than on fertile lowland soils. Tree diameter had no influence on average wood density. Regarding within-tree variation, wood density does not vary from pith to bark.

- Conclusion These results help fill the gaps in wood properties database for tree forest species in Madagascar.

Keywords Madagascar $\cdot$ Modelling ·

Species light requirement $\cdot$ Soil types $\cdot$ Wood density

\section{Introduction}

Wood is a complex material with outstanding physical and mechanical properties. Density is one of its most important technological and ecological properties. Wood density is connected to several functional tree traits (Chave et al. 2009; Nock et al. 2009) and is correlated with some wood mechanical properties such as dynamic bending strength, modulus of elasticity and compression strength (Machado et al. 2014). Therefore, wood density provides guidance on the potential uses for a particular wood species. Moreover, wood density reflects the amount of biomass per unit volume of tree trunk and thus is one of the predictor variables usually used in allometric equations to estimate forest aboveground biomass (Chave et al. 2009; Henry et al. 2010).

Several factors can explain the intra- and inter- tree variations of wood density. According to Chave et al. (2009), there is a relation between the wood density and several traits across 
Table 1 Number of trees per species, with diameter class and their respective diameters

\begin{tabular}{|c|c|c|c|c|c|c|}
\hline \multirow[t]{2}{*}{ Scientific name } & \multirow[t]{2}{*}{ Family } & \multicolumn{3}{|c|}{ Number of trees studied } & \multicolumn{2}{|c|}{ Average DBH (Std) (cm) } \\
\hline & & SD & $\mathrm{BD}$ & Total & SD & $\mathrm{BD}$ \\
\hline Albizia gummifera (J.F., Gmel.) C.A. Smith* & Fabaceae & 5 & 4 & 9 & $13.62(1.23)$ & $19.48(5.07)$ \\
\hline Anthocleista madagascariensis Baker* & Gentianaceae & 3 & 3 & 6 & $12.3(0.78)$ & $22.67(5.8)$ \\
\hline Bosqueia danguyana Leandri & Moraceae & 5 & 3 & 8 & $9.22(3.07)$ & $20.63(3.96)$ \\
\hline Calophyllum sp. & Calophyllaceae & 5 & 3 & 8 & $11.07(2.01)$ & $22.3(3.58)$ \\
\hline Chrysophyllum boivinianum (Pierre) Baehni & Sapotaceae & 6 & 5 & 11 & $10.68(1.25)$ & $22.26(2.6)$ \\
\hline Dilobeia thouarsii Roem. \& Schult & Proteaceae & 5 & 4 & 9 & $11.16(2.36)$ & $19.53(3.86)$ \\
\hline Dombeya lucida Baill.* & Malvaceae & 5 & 5 & 10 & $12.02(1.4)$ & $21.14(3.57)$ \\
\hline Erythroxyllum corymbosum Boivin ex Baill. & Erythroxylaceae & 3 & 3 & 6 & $9.2(2.78)$ & $18.97(3.76)$ \\
\hline Harungana madagascariensis Lamarck ex. Poiret & Hypericaceae & 6 & 7 & 13 & $11.67(1.46)$ & $18.3(3.6)$ \\
\hline Ilex mitis (L.) Radlkofer* & Aquifoliaceae & 6 & 5 & 11 & $10.97(3.36)$ & $16.26(0.86)$ \\
\hline Macaranga cuspidata Boivin ex Baill. & Euphorbiaceae & 6 & 3 & 9 & $11.1(3.42)$ & $18.03(1.85)$ \\
\hline Micronychia tsiramiramy H. Perrier & Anacardiaceae & 5 & 5 & 10 & $11.04(1.44)$ & $18.38(1.59)$ \\
\hline Mussaenda sp. Linnaeus & Rubiaceae & 5 & 3 & 8 & $11.42(1.61)$ & $19.47(3.21)$ \\
\hline Nuxia capitata Baker & Stilbaceae & 5 & 4 & 9 & $10.52(2.03)$ & $18.58(3.51)$ \\
\hline Ocotea sp.(1)** & Lauraceae & 3 & 3 & 6 & $9.73(0.9)$ & $20.18(4.05)$ \\
\hline Ocotea $\mathrm{sp} \cdot(2)^{* *}$ & Lauraceae & 5 & 4 & 9 & $12.12(1.72)$ & $19.88(3.35)$ \\
\hline Protorhus ditimena H. Perrier* & Anacardiaceae & 5 & 5 & 10 & $9.48(1.8)$ & $18.94(1.31)$ \\
\hline Ravensara acuminata (Willd ex Meisen) Baillon & Lauraceae & 5 & 5 & 10 & $11.56(2.78)$ & $19.68(1.06)$ \\
\hline Ravensara crassifolia (Baker) Danguy & Lauraceae & 6 & 4 & 10 & $10.7(3.1)$ & $16.46(1.03)$ \\
\hline Schefflera longipedicellata (Lecomte) Bernardi & Araliaceae & 5 & 5 & 10 & $12.37(2.05)$ & $18.02(2.17)$ \\
\hline Schefflera vantsilana (Baker) Bernardi & Araliaceae & 4 & 5 & 9 & $9.2(1.87)$ & $19.46(4.39)$ \\
\hline Syzygium cumini (L.) Skeels* & Myrtaceae & 3 & 3 & 6 & $11.2(1.61)$ & $16.8(0.53)$ \\
\hline Uapaca densifolia Baker* & Phyllanthaceae & 3 & 4 & 7 & $9.48(1.31)$ & $22.28(1.83)$ \\
\hline
\end{tabular}

$S D$ small diameter $(5 \mathrm{~cm} \leq \mathrm{DBH}<15 \mathrm{~cm}), B D$ big diameter $(\mathrm{DBH} \geq 15 \mathrm{~cm}), D B H$ diameter at breast height, Std standard deviation

*Indicates the seven most abundant species according to Rajaonera (2008)

**The two species belonging to Ocotea genus could not be defined. Their botanical characteristics are different

the whole-plant, including leaf size, minimum leaf water potential and perhaps rooting depth. The radial variation in wood density represents tree strategies throughout its development by investing in height growth or investing in wood tissue for structural support. Wood density is related to the light requirement of the species. Previous studies have shown that pioneer species have low density while emerging species have intermediate density and sub-canopy slow-growing species have high density (King et al. 2006; Muller-Landau 2004; Van Gelder et al. 2006). When studying 1653 trees across the Amazon Basin, Patino et al. (2009) found that altitude is negatively correlated with the density whereas temperature is positively correlated with the density. Because of the terrain slope and competition for soil reserves, soil types affect the dynamics of tree growth, thus the variations in wood properties. A steep terrain is particularly sensitive to erosion, so soil resources are easily eroded. To adapt itself to this environment, tree develops wood with higher physical and mechanical properties (Coutand et al. 2004; Wimmer et al. 2002).
Density varies also within a given tree. The radial variation of wood density can be explained first by the gradual transition from juvenile to mature wood (Fukazawa 1984). The ageing of the cambial meristem causes the intra-tree density variation, as well as a pithto-bark increase in fibre length and in vessel diameter (Thibaut et al. 1997). The evolution of wood extractives from pith to bark also accounts for density variation within tree (Guilley 2000).

Several studies on the variations of wood density with distance from the pith have been carried out on temperate species (McLean et al. 2011; Machado et al. 2014) and tropical wood from South America (Montes et al. 2007), Africa (Henry et al. 2010) and Asia (Nock et al. 2009). According to these authors, wood density of fast-growing pioneer species increases from pith to bark, whereas slower-growing trees exhibit the reverse pattern. The stiffness of the juvenile wood decreases from pith to bark for primary forest trees, whereas it 


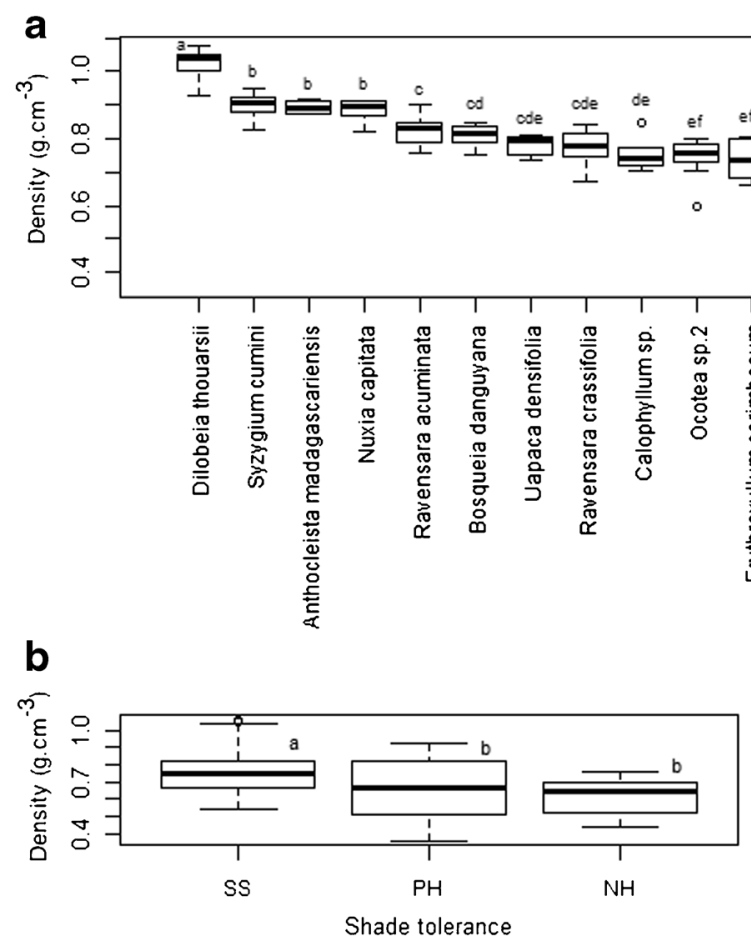

Fig. 1 Average wood density according to a tree species, b light requirement-SS semi-shade-tolerant, $P L D$ pioneer light demander, $N L D$ nomad light demander, c soil types $-A F$ acric ferralsol, $O F$ orthic ferralsol, $X F$ xanthic ferralsol, $E$ entisols, $S L C$ soils of lowland complex. Box plot

increases for plantation trees. Increments are greater in wet tropical forests than in drier tropical forests. However, to our knowledge, there was no study yet about the variation of wood in natural forests of Madagascar. Given that $96 \%$ of Malagasy tree and shrub species are endemic (Schatz 2000), we address the following question: Do internal (species, tree diameter) and external factors (soil types) affect wood density and its radial variation for native rainforest tree species? Three hypotheses are tested: (i) Species have different average density and different radial variation patterns. This difference is explained by the species light requirement. We expect pioneer species to have less dense wood and increasing density from pith to bark and a reverse pattern in shade-tolerant species; (ii) Average wood density is different for large and small trees; (iii) Soil types influence wood density between trees and its radial variation. We expect less dense wood and increasing density from pith to bark in very fertile stands.

\section{Material and methods}

The experimental approach consisted of three steps: (i) determination of the factors underlying the variation of wood density - species, tree diameter, distance from the pith, soil types; (ii) measurement of the wood density in laboratory; (iii) development of the models of radial variation of density by incorporating the four factors of variation.

\subsection{Study area}

The study was carried out in Mandraka natural forest, District of Manjakandriana, Region Analamanga, Madagascar $\left(47^{\circ} 54^{\prime}-47^{\circ} 56^{\prime} \mathrm{E}\right.$ and $\left.18^{\circ} 53^{\prime}-18^{\circ} 55^{\prime} \mathrm{S}\right)$. It is located $67 \mathrm{~km}$ East of Antananarivo. Mandraka is managed by the Forestry Department, School of Agronomy, University of Antananarivo. Annual precipitation averages $2300 \mathrm{~mm}$. The wettest months are from December to March with maximum rainfall in January $(342 \mathrm{~mm}$ ). There is no ecologically dry month. Temperatures range from 13.7 to $20.2^{\circ} \mathrm{C}$ with an annual average of $17.5^{\circ} \mathrm{C}$. The relatively high elevation $(800-1300 \mathrm{~m})$ confers a permanent relative humidity with an average of $82 \%$. The climate is tropical fresh and humid. The terrain is rugged, characterized by overall slopes of $50 \%$ but reaching $90 \%$ in some places (Rajaonera 2008). The natural vegetation is an evergreen montane forest, characterized by high tree density, reduced height and pluristrata structures. A recent forest survey identified 73 tree species distributed within 
Table 2 Linear model of intra-tree wood density variation according to the three factors studied

\begin{tabular}{|c|c|c|c|c|c|c|}
\hline Factors & Parameter & Estimate & Std. error & $t$ value & $\operatorname{Pr}(>|t|)$ & \\
\hline \multirow[t]{7}{*}{ Tree diameter } & (Intercept) & 0.670397 & 0.013347 & 50.23 & $<2 \mathrm{e}-16$ & $* * *$ \\
\hline & Distance to pith Dp & 0.007174 & 0.003025 & 2.371 & 0.0179 & $*$ \\
\hline & Diameter & & & & & \\
\hline & Small diameter & 0.021917 & 0.023336 & 0.939 & 0.3479 & - \\
\hline & Interaction Diameter $\times \mathrm{Dp}$ & & & & & \\
\hline & Small diameter $\times \mathrm{Dp}$ & -0.004962 & 0.008087 & -0.614 & 0.5397 & - \\
\hline & $\begin{array}{l}\text { Residual standard error: } 0.1556 \\
\text { Multiple R-squared: } 0.006677 \text {, Adju } \\
\text { F-statistic: } 1.904, p \text { value: } 0.1273 \\
P \text { values for Diameter and Diameter } \\
\left.R^{2} \text { (model }\right)=1.27 \%, R^{2} \text { (Diameter) }\end{array}$ & $\begin{array}{l}\text { squared: } 0.03 \\
\text { test are for } s \\
003 \%, R^{2}(D\end{array}$ & $\begin{array}{l}\text { at difference } \\
96 \%, R^{2}(D\end{array}$ & $\begin{array}{l}\text { ve to "Big } \\
r \times D p)=\end{array}$ & $\begin{array}{l}\text { eter" } \\
6\end{array}$ & \\
\hline \multirow[t]{9}{*}{ Light requirement } & (Intercept) & 0.61 & 0.03 & 17.80 & $<2 \mathrm{e}-16$ & $* * *$ \\
\hline & Distance to pith Dp & 0.004 & 0.01 & 0.47 & 0.64 & - \\
\hline & Light requirement & & & & & \\
\hline & Pioneer light demander & 0.03 & 0.04 & 0.90 & 0.37 & - \\
\hline & Semi-shade-tolerant & 0.14 & 0.04 & 3.64 & 0.00 & $* * *$ \\
\hline & Interaction: Light requirement $\times \mathrm{Dp}$ & & & & & \\
\hline & Pioneer light demander $\times \mathrm{Dp}$ & 0.002 & 0.01 & 0.20 & 0.84 & - \\
\hline & Semi-shade-tolerant $\times \mathrm{Dp}$ & -0.001 & 0.01 & -0.10 & 0.92 & - \\
\hline & $\begin{array}{l}\text { Residual standard error: } 0.1509 \\
\text { Multiple R-squared: } 0.1064, \text { Adjuste } \\
\text { F-statistic: } 18.69, p \text { value: }<2.2 \mathrm{e}-16 \\
P \text { values for Light requirement and } L \\
R^{2} \text { (model) }=11.4 \%, R^{2} \text { (Light requ }\end{array}$ & $\begin{array}{l}\text { uared: } 0.100 \\
\text { quirement } \times \\
t)=10.2 \% \text {, }\end{array}$ & $\begin{array}{l}\text { are for signi } \\
\text { ht requirem }\end{array}$ & $\begin{array}{l}\text { lifferences } \\
0.8 \%, R^{2}\end{array}$ & $\begin{array}{l}\text { e to "Non } \\
\text { requirem }\end{array}$ & $\begin{array}{l}\text { tdemander" } \\
\text { o) }=0.4 \%\end{array}$ \\
\hline \multirow[t]{13}{*}{ Soil type } & (Intercept) & 0.41 & 0.06 & 6.49 & $<0.001$ & $* * *$ \\
\hline & Distance to pith Dp & 0.004 & 0.02 & 0.25 & 0.80 & - \\
\hline & Soil type & & & & & \\
\hline & Xanthic ferralsol & 0.28 & 0.06 & 4.35 & $<0.001$ & $* * *$ \\
\hline & Orthic ferralsol & 0.28 & 0.07 & 4.26 & $<0.001$ & $* * *$ \\
\hline & Acric and xanthic ferralsol & 0.28 & 0.07 & 3.93 & $<0.001$ & $* * *$ \\
\hline & Entisols & 0.16 & 0.10 & 1.63 & 0.10 & - \\
\hline & Interaction: Soil type $\times \mathrm{Dp}$ & & & & & \\
\hline & Xanthic ferralsol $\times \mathrm{Dp}$ & 0.002 & 0.02 & 0.12 & 0.91 & - \\
\hline & Orthic ferralsol $\times \mathrm{Dp}$ & -0.01 & 0.02 & -0.41 & 0.68 & - \\
\hline & Acric and xanthic ferralsol $\times \mathrm{Dp}$ & 0.01 & 0.02 & 0.39 & 0.70 & - \\
\hline & Entisols $\times \mathrm{Dp}$ & 0.01 & 0.03 & 0.38 & 0.71 & - \\
\hline & $\begin{array}{l}\text { Residual standard error: } 0.1475 \\
\text { Multiple R-squared: } 0.1141, \text { Adjuste } \\
\text { F-statistic: } 12.07, p \text { value: }<2.2 \mathrm{e}-16 \\
P \text { values for Soil type and Soil type } \\
R^{2} \text { (model) }=12.5 \%, R^{2} \text { (Soil type) }\end{array}$ & $\begin{array}{l}\text { uared: } 0.1046 \\
\text { st are for sig } \\
2 \%, R^{2}(\mathrm{Dp}\end{array}$ & $\begin{array}{l}\text { difference } \\
\%, R^{2}(S o\end{array}$ & $\begin{array}{l}\text { e to "Soi } \\
\mathrm{Dp})=\end{array}$ & and $c o$ & \\
\hline
\end{tabular}

Wood density is in g.cm-3

*** significant at the $0.1 \%$ level, ** significant at the $1 \%$, * significant at the $5 \%,-$ non significant

52 genera and 42 families, most of which are endemic. Secondary formations locally called savoka represent about $30 \%$ of the natural area and are composed mainly of pioneer, light-demanding species. This study sampled trees from both the primary and secondary forest formations that cover a total of 14.51 ha.

\subsection{Species selection and diameter threshold}

We selected the 23 most abundant native species both in the primary and secondary forests. The species identified by Rajaonera (2008) as most abundant were all included (indicated by the symbol * in Table 1). 
Table 3 Linear model of the intra-tree wood density variation for the 23 species

\begin{tabular}{|c|c|c|c|c|c|}
\hline Parameter & Estimate & Std. error & $t$ value & $\operatorname{Pr}(>|t|)$ & \\
\hline (Intercept) & 0.780 & 0.020 & 38.784 & $<2 \mathrm{e}-16$ & $* * *$ \\
\hline Distance to pith Dp & 0.001 & 0.005 & 0.169 & 0.8662 & - \\
\hline \multicolumn{6}{|l|}{ Species sp } \\
\hline Syzygium cumini & 0.113 & 0.032 & 3.513 & 0.0005 & $* * *$ \\
\hline Dilobeia thouarsii & 0.220 & 0.030 & 7.420 & $<0.001$ & $* * *$ \\
\hline Schefflera longipedicellata & -0.214 & 0.029 & -7.294 & $<0.001$ & $* * *$ \\
\hline Anthocleista madagascariensis & 0.139 & 0.027 & 5.048 & $<0.001$ & $* * *$ \\
\hline Ilex mitis & -0.158 & 0.028 & -5.657 & $<0.001$ & $* * *$ \\
\hline Micronychia tsiramiramy & -0.215 & 0.029 & -7.429 & $<0.001$ & $* * *$ \\
\hline Ocotea sp.(2) & -0.072 & 0.028 & -2.552 & 0.0109 & $*$ \\
\hline Ocotea sp.(1) & -0.121 & 0.031 & -3.944 & 0.0001 & $* * *$ \\
\hline Chrysophullum boivinianum & -0.102 & 0.027 & -3.838 & 0.0001 & $* * *$ \\
\hline Protorhus ditimena & -0.124 & 0.029 & -4.273 & $<0.001$ & $* * *$ \\
\hline Dombeya lucida & -0.161 & 0.028 & -5.806 & $<0.001$ & $* * *$ \\
\hline Ravensara crassifolia & 0.014 & 0.029 & 0.474 & 0.6355 & - \\
\hline Harungana madagascariensis & -0.350 & 0.027 & -13.015 & $<2 \mathrm{e}-16$ & $* * *$ \\
\hline Macaranga cuspidata & -0.336 & 0.034 & -9.779 & $<2 \mathrm{e}-16$ & $* * *$ \\
\hline Bosqueia danguyana & 0.011 & 0.029 & 0.390 & 0.6968 & - \\
\hline Schefflera vantsilana & -0.234 & 0.027 & -8.577 & $<2 \mathrm{e}-16$ & $* * *$ \\
\hline Calophyllum sp. & -0.069 & 0.028 & -2.438 & 0.0150 & $*$ \\
\hline Nuxia capitata & 0.099 & 0.029 & 3.387 & 0.0007 & $* * *$ \\
\hline Mussaenda sp. & -0.292 & 0.033 & -8.707 & $<2 \mathrm{e}-16$ & $* * *$ \\
\hline Erythroxyllum corymbosum & -0.068 & 0.033 & -2.088 & 0.0372 & $*$ \\
\hline Ravensara acuminata & 0.047 & 0.028 & 1.711 & 0.0874 & - \\
\hline Albizia gummifera & -0.194 & 0.027 & -7.169 & $<0.001$ & $* * *$ \\
\hline \multicolumn{6}{|l|}{ Interaction sp. $\times \mathrm{Dp}$} \\
\hline Syzygium cumini $\times \mathrm{Dp}$ & -0.002 & 0.008 & -0.237 & 0.8127 & - \\
\hline Dilobeia thouarsii $\times \mathrm{Dp}$ & 0.002 & 0.008 & 0.315 & 0.7529 & - \\
\hline Schefflera longipedicellata $\times \mathrm{Dp}$ & -0.001 & 0.008 & -0.085 & 0.9326 & - \\
\hline Anthocleista madagascariensis $\times \mathrm{Dp}$ & -0.006 & 0.006 & -1.152 & 0.2495 & - \\
\hline Ilex mitis $\times \mathrm{Dp}$ & -0.002 & 0.007 & -0.257 & 0.7976 & - \\
\hline Micronychia tsiramiramy $\times \mathrm{Dp}$ & 0.006 & 0.008 & 0.797 & 0.4256 & - \\
\hline Ocotea $\mathrm{sp} .(2) \times \mathrm{Dp}$ & 0.011 & 0.007 & 1.524 & 0.1279 & - \\
\hline Ocotea $\mathrm{sp} .(1) \times \mathrm{Dp}$ & 0.0001 & 0.007 & 0.027 & 0.9783 & - \\
\hline Chrysophullum boivinianum $\times \mathrm{Dp}$ & -0.002 & 0.006 & -0.240 & 0.8103 & - \\
\hline Protorhus ditimena $\times \mathrm{Dp}$ & 0.0001 & 0.007 & -0.018 & 0.9860 & - \\
\hline Dombeya lucida $\times \mathrm{Dp}$ & 0.008 & 0.007 & 1.111 & 0.2669 & - \\
\hline Ravensara crassifolia $\times \mathrm{Dp}$ & -0.010 & 0.008 & -1.267 & 0.2054 & - \\
\hline Harungana madagascariensis $\times$ Dp & 0.005 & 0.006 & 0.825 & 0.4093 & - \\
\hline Macaranga cuspidata $\times \mathrm{Dp}$ & 0.017 & 0.011 & 1.558 & 0.1197 & - \\
\hline Bosqueia danguyana $\times \mathrm{Dp}$ & 0.008 & 0.007 & 1.144 & 0.2530 & - \\
\hline Schefflera vantsilana $\times \mathrm{Dp}$ & -0.003 & 0.006 & -0.443 & 0.6577 & - \\
\hline Calophyllum sp. $\times \mathrm{Dp}$ & 0.006 & 0.007 & 0.870 & 0.3847 & - \\
\hline Nuxia capitata $\times \mathrm{Dp}$ & 0.003 & 0.007 & 0.342 & 0.7328 & - \\
\hline Mussaenda sp. $\times \mathrm{Dp}$ & 0.001 & 0.009 & 0.135 & 0.8925 & - \\
\hline Erythroxyllum corymbosum $\times \mathrm{Dp}$ & 0.011 & 0.009 & 1.244 & 0.2140 & - \\
\hline Ravensara acuminata $\times \mathrm{Dp}$ & -0.002 & 0.007 & -0.338 & 0.7358 & - \\
\hline Albizia gummifera $\times \mathrm{Dp}$ & 0.001 & 0.006 & 0.115 & 0.9085 & - \\
\hline
\end{tabular}

Residual standard error: 0.06387 
Table 3 (continued)

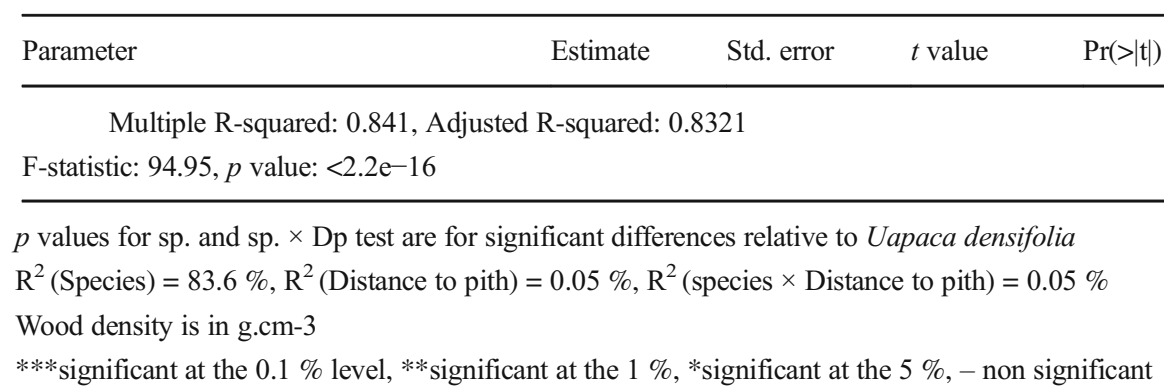

According to Rajaonera (2008), more than a half of the trees in Mandraka have a diameter at breast height $(\mathrm{DBH})$ between 5 and $15 \mathrm{~cm}$. Trees with $\mathrm{DBH}$ above $40 \mathrm{~cm}$ are almost nonexistent. Thus, in order to understand whether tree diameter affects the variability of wood density, we considered two classes: (1) small trees, $5 \mathrm{~cm} \leq$ diameter $<15 \mathrm{~cm}$ and (2) large trees, diameter $\geq 15 \mathrm{~cm}$. We randomly selected a minimum of three trees per diameter class that is a minimum of six trees per species. Given the previous threshold, the number of trees studied per species was different because of the random sampling used. In total, 204 trees were sampled (Table 1). The DBH ranged from 9.2 to $13.6 \mathrm{~cm}$ and from 16.3 to $22.7 \mathrm{~cm}$ for small trees and larger ones, respectively.

We sampled pith-to-bark wood cores using an electric drill powered by a generator. The cores had a diameter of $15 \mathrm{~mm}$ and were extracted at DBH level. Because of the possible existence of tension wood from the sloping ground, the pithto-bark wood cores were taken from the downslope side of the trees.

\subsection{Determination of species light requirement}

Plants are classified on the basis of their relative light requirements for overall vegetative development as heliophytes and sciophytes (Sharma 2005). To date, there have been few data in the literature regarding the light requirement of native tree species in Madagascar. Several methods have been used in the literature to determine the light requirements of species. These include the study of the natural regeneration, the survival and the growth of seedlings in different light conditions (Ducrey and Labbé 1985), and the use of hemispherical photographs taken directly above the crown of each sapling (Baltzer and Thomas 2007). But none of these practical methods were available to us, thus forcing us to opt for an empirical one. According to Rollet (1984), tree diameter distribution reflects the current position of each species in the stand and is the result of a 'development strategy' (growth and mortality) in the whole ecosystem. Therefore, there are striking differences between size- class distribution of light-demanding and shade-tolerant species in mature tropical rainforest. Several authors (e.g., Dupuy et al. 1998; Hall and Swaine 1981; Whitmore 1990) used the distribution curves of the species abundance per diameter class in 1 ha of forest to determine species light requirement. Therefore, we assessed the light requirement using the same method.

Mandraka forest has been modified from its original state by various natural and anthropogenic pressures. Thus, to validate the approach, we simultaneously used three forest survey results on mid-elevation rainforests: (1) the national forestry and ecological inventory IEFN (MEF 1996) which covered all types of forests including mid-elevation rainforests, (2) the inventory done in the Anjozorobe-Angavo forest corridor (Goodman et al. 2007) as $74 \%$ of Mandraka species are listed in this corridor, and (3) the forest inventory carried in Mandraka forest by Rajaonera (2008).

Using data from these three sources, species light requirements were determined based on population structure by establishing the distribution curves of the species abundance per diameter class. The resulting curves were compared with those of Rollet (1984) in order to identify the light requirement of each species.

\subsection{Soil types in Mandraka}

We recorded the geographical coordinates and altitude of each studied tree. Combining these data with results from a soil survey done by Rajoelison et al. (2007) in Mandraka, we were able to determine the type of soil on which the trees were growing. Five types of soils were identified: acric ferralsol (AF), xanthic ferralsol (XF), orthic ferralsol (OF), entisols (E) and soils of lowland complex (SLC). All types of soils are ferralitic with lumpy and polyhedric textures. They differ in the degree of rejuvenation by the occurrence of primary minerals at a certain depth. The more we go downslope, the more we

Fig. 2 Pith-to-bark variation of wood density of the 23 species studied. Red lines represent best-fit linear regression models. Species are ordered by alphabetical order of family 
ANACARDIACEAE
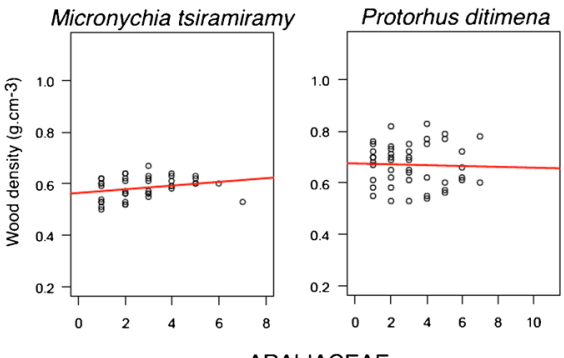

ARALIACEAE
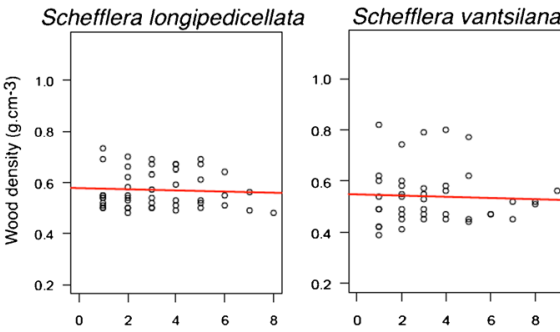

FABACEAE

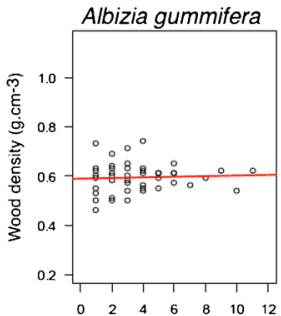

GENTIANACEAE

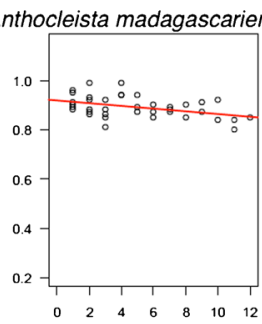

LAURACEAE
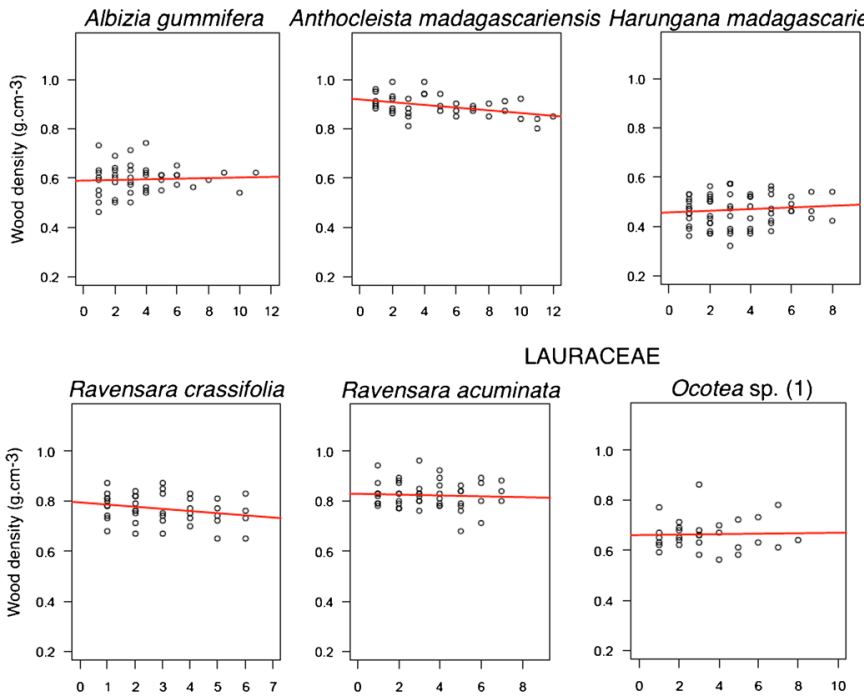

\section{sis}

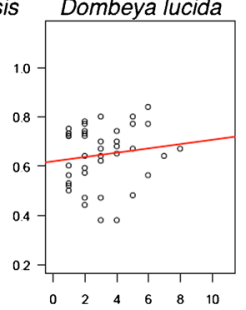

Erythroxyllum corymbosum

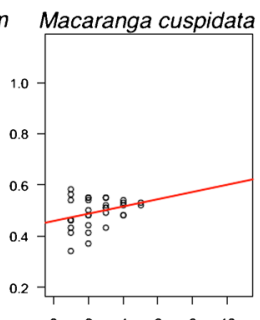

\section{MORACEAE}
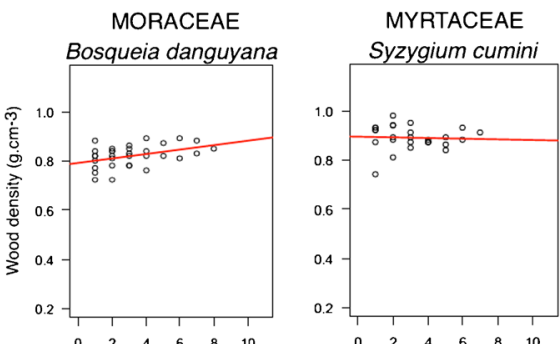

PHYLLANTHACEAE
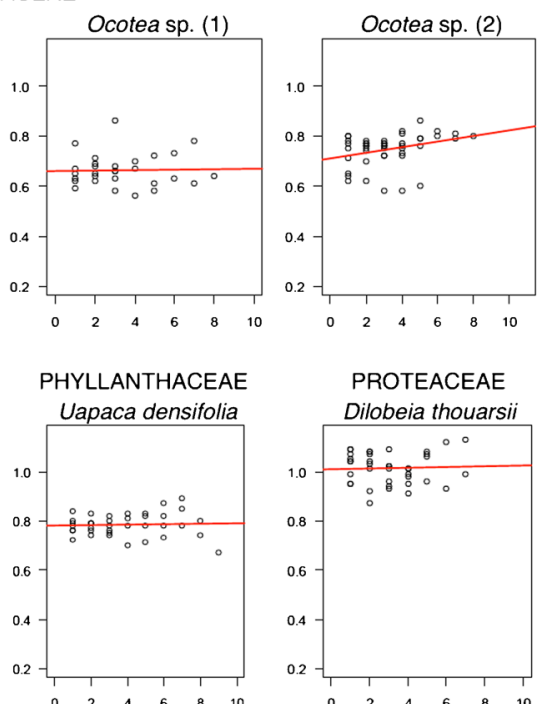

RUBIACEAE

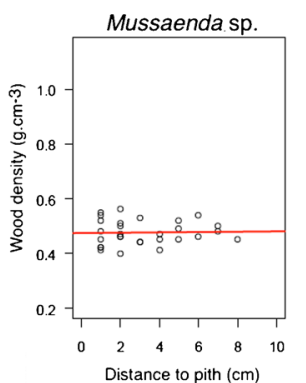

SAPOTACEAE

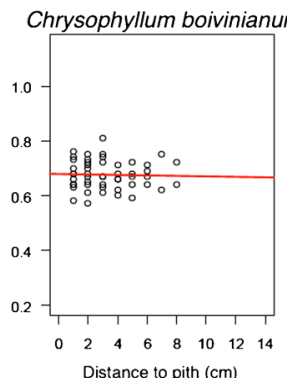

Distance to pith $(\mathrm{cm})$
STILBACEAE

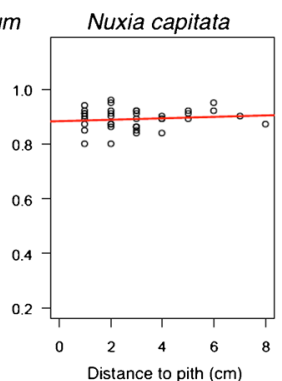

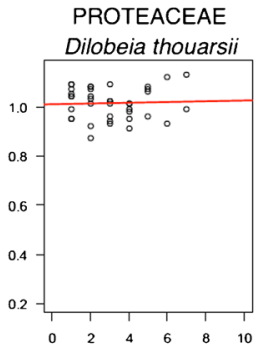


find primary minerals. Soils of lowland complex can be entisols rich in humus layers or hydromorphic soils.

\subsection{Recording wood density}

In order to study the radial variation of density, each core was cut into $1 \mathrm{~cm}$-long segments, starting at $0.5 \mathrm{~cm}$ from the pith. Segments containing bark and pith were excluded. In total, 204 core samples were collected. The number of cores obtained per species ranged from 6 to 13. In total, 2342 segments were obtained from these cores. The density of a segment was calculated as its weight divided by its volume, both measured at $12 \%$ humidity (stabilised in a climatic chamber at $20{ }^{\circ} \mathrm{C}$ and $65 \%$ relative humidity). The weight was measured with a precision scale with $0.01 \mathrm{~g}$ resolution. We used the Archimedes water displacement method to measure the volume (Chave et al. 2006). Wood density of a tree was the average density of the pith-to-bark segments. Similarly, the density for a species was the average of the densities of all the sampled trees belonging to that species.

\subsection{Modelling the variation in wood density among trees and within a tree}

Statistical analysis was performed with the $\mathrm{R}$ software (R Development Core Team 2012). For all species, we first calculated the mean, the range and the standard deviation of the density. We then run an analysis of variance to assess the effect of the following factors: species, tree diameter, soil types and distance from pith on the wood density variation. Fisher's LSD test was used to identify significant differences between each level of factors that explained the variability of wood density.

Models of the radial variability of the density were developed based on a linear mixed-effects model (Nock et al. 2009). In this linear model, the factor species was considered as a random effect while diameter, soil type and distance from pith were taken to have fixed effects. Moreover, the interaction between factors was taken into account, given that the effects of these factors are nonadditive. Therefore, the final linear mixed-effects model was:

$D_{i j k}=\beta_{0}+\beta_{1} D p_{i j}+\beta_{2} F_{k}+\beta_{3} F_{k} D p_{i j}+\varepsilon_{i j k}$ where $D_{i j k}$ is the wood density for the i-th segment of the $\mathrm{j}$-th tree of the $\mathrm{k}$-th species, $D p_{i j}$ is the distance to the pith, $F_{k}$ is the factor considered and $\beta_{0}, \beta_{1}, \beta_{2}, \beta_{3}$ are the fixed effects, $\varepsilon_{i j k}$ are the errors. The goodness of fit of the model was assessed with the coefficient of determination $R^{2}$.

\section{Results}

\subsection{Effect of tree species and diameter on the average wood density}

Different species displayed significantly different wood densities $(p<0.001, \alpha=0.05, \mathrm{df}=22)$. Average wood density of the 23 species ranged from 0.47 to 1.01 (Fig. 1a). Harungana madagascariensis and Dilobeia thouarsii displayed respectively the lowest and highest average densities. Furthermore, the distribution of the minimum and maximum density values for each species showed the existence of within-species variability. The factor tree diameter had no influence on the average wood density (Table 2).

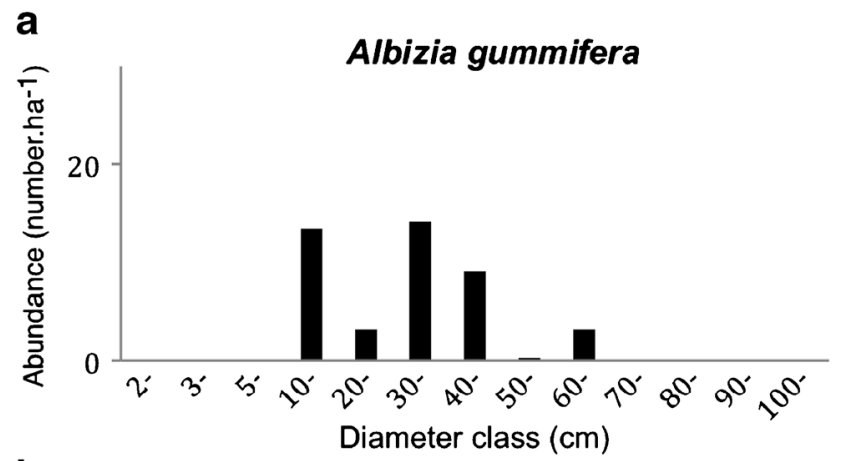

b

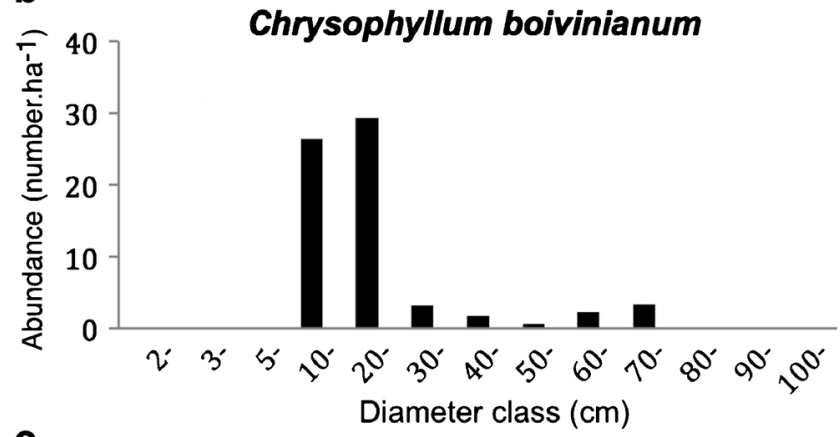

C

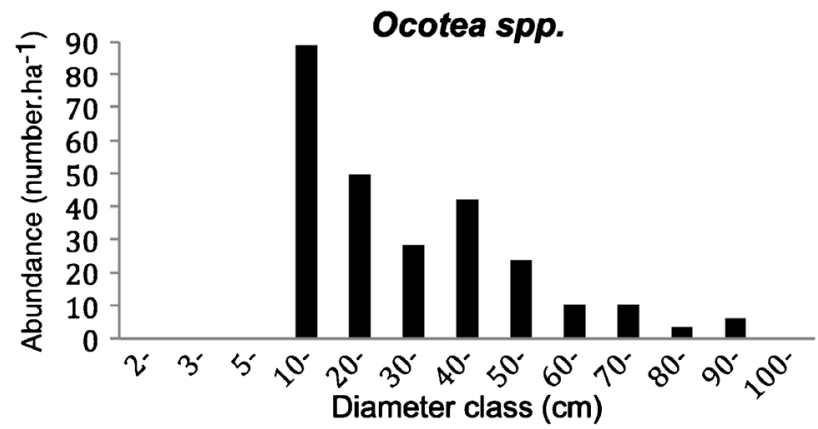

Fig. 3 Light requirement of some species in the study site. Typical distribution of light demander pioneer species e.g., Albizia gummifera (a), light demander nomad species e.g., Chrysophyllum boivinianum (b), edifice shade-tolerant species e.g., Ocotea spp. (c). Curves derived from combined data of the three inventories (Goodman et al. 2007, MEF 1996, Rajaonera 2008) 
Table 4 Light requirements of the 23 species studied

\begin{tabular}{|c|c|c|}
\hline Species behaviours & Group & Taxa \\
\hline Light demanders (Sun species) & Pioneer & $\begin{array}{l}\text { Albizia gummifera } \\
\text { Nuxia capitata } \\
\text { Schefflera longipedicellata } \\
\text { Schefflera vantsilana } \\
\text { Harungana madagascariensis } \\
\text { Ravensara crassifolia } \\
\text { Ravensara acuminata } \\
\text { Anthocleista madagascariensis } \\
\text { Dombeya lucida } \\
\text { Macaranga cuspidata }\end{array}$ \\
\hline & Nomad & $\begin{array}{l}\text { Chrysophyllum boivinianum } \\
\text { Mussaenda } \mathrm{sp.}\end{array}$ \\
\hline Shade-tolerant (Shade species) & Semi-shade-tolerant & $\begin{array}{l}\text { Protorhus ditimena } \\
\text { Calophyllum sp. } \\
\text { Ocotea sp.(1) } \\
\text { Ocotea sp.(2) } \\
\text { Bosqueia danguyana } \\
\text { Syzygium cumini } \\
\text { Uapaca densifolia } \\
\text { Dilobeia thouarsii } \\
\text { Ilex mitis }\end{array}$ \\
\hline
\end{tabular}

Tree distribution of the two species Erythroxyllum corymbosum and Micronychia tsiramiramy could not be identified because none of the inventories used have complete information on their abundance

\subsection{Effect of soil types on the average wood density}

Soil type had a significant effect on the average wood density at the $5 \%$ level (Table 2 ). The wood density of trees on soils of the lowland complex $\left(0.41 \mathrm{~g} . \mathrm{cm}^{-3}\right)$ was significantly lower than on the three ferralsol and entisol $\left(0.69 \mathrm{~g} . \mathrm{cm}^{-3}\right)$ (Fig. 1c). Average wood densities did not differ between the three ferralsols (Table 2).

\subsection{Effect of light requirement on the average wood density}

Light requirement had an effect on the average wood density (Table 2). The average wood density of shade-tolerant species $\left(0.75 \mathrm{~g} . \mathrm{cm}^{-3}\right)$ was significantly greater than that of light-demanding species $\left(\right.$ nomad $=0.61 \mathrm{~g} . \mathrm{cm}^{-3}$, pioneer $=0.64{\mathrm{~g} . \mathrm{cm}^{-3}}^{\text {) }}$ at the $5 \%$ level (Fig. 1b).

\subsection{3. Radial variation of wood density}

Table 3 shows that the distance from pith had no effect on the intra-tree density variability since the part of the variability due to this factor was low $\left(R^{2}=0.05 \%\right)$. Density increased slightly from pith to bark for 13 species, decreased for 8 species and did not vary for 2 species (Fig. 2). None of the factors (species, tree diameter, soil type) had an influence on the radial variation of wood density (Table 2).

\section{Discussion}

\subsection{Effect of species on wood density}

The results of this study show that species had an effect on the average wood density (Table 2). Several authors suggested tree light requirement as one of the main reasons for the difference in wood density between species (e.g., Van Gelder et al. 2006; Muller-Landau 2004). Light-demanding species are fast-growing, which favours a lower wood density than shade-tolerant, slowgrowing species.

The analysis of the diameter class using the data from the three forest surveys showed three groups of species light requirements. Three examples of distributions are shown for each group of light requirement (Fig. 3). For example, based on the models established by Rollet (1984), Albizia gummifera (Fig. 3a) is a light-demanding pioneer species 
because of its erratic distribution. This species requires full light from the beginning to the end of its life cycle. The large number of individuals with small diameters in the Mandraka forest indicated the presence of a previous canopy gap that has been restored. Chrysophyllum boivinianum (Fig. 3b) is a lightdemanding nomad species that can germinate in the shadows of the other trees, but requires light to grow higher. The "balanced L" distribution for species like Ocotea sp. is close to the negative exponential distribution model (Fig. 3c). This model is characteristic of edifice shade-tolerant species that regenerate in the shade of the stand and may be able to survive in the shade throughout its entire life. The light requirements of the other species are shown in Table 4 . The analysis of the distribution of trees by diameter class showed that ten species are light-demanding pioneers, two are nomadic and nine are semishade-tolerant. Sun species $(57 \%)$ were more common than shade species $(43 \%)$.

A number of studies have suggested that light-demanding species have greater growth potential than shade-tolerant species, regardless of the light environment (Baltzer and Thomas 2007; Nock et al. 2009). The results of this study are in accordance with the literature. Thus, for light-demanding species, low wood density facilitates rapid canopy ascension whereas for shade-tolerant species, higher wood density contributes to higher survival beneath the canopy.

\subsection{Effect of tree diameter on wood density}

Tree diameter had no influence on the within- and betweentree variability of wood density. This finding is inconsistent with the results from similar studies. For example, Woodcock and Shier (2003) and Chowdhury et al. (2013) found that small-diameter trees in temperate forests and plantations have lower density than larger trees. In these studies, the trees reached $60 \mathrm{~cm}$ in diameter. The structure of a temperate forest is different from that of a tropical mountain forest; this latter being largely dominated by small-diameter trees (Rajaonera 2008). The maximum tree diameter recorded in this study was indeed below $30 \mathrm{~cm}$. It would have been interesting to study the effect of tree age (De Castro et al. 1993) but the fact that the studied species do not produce annual growth rings hindered that investigation.

\subsection{Effect of soil types on wood density}

Soil types influence the average wood density between trees. The average wood density is higher on poor ferralitic soils than on lowland ones. Uphill and along the slope, the soil is chemically poor, dominated by young loamy soils that feature low structural stability and are easily eroded. In contrast, soils in the lowlands are more fertile because of the accumulation of nutrients from the higher ground due to erosion (Rajoelison et al. 2007). For the same reason, entisol contains more nutrients, especially potassium. This study suggests that tree growth is moderate on poor soil, subsequently enabling the wood to become more densely structured (Baker et al. 2004; Muller-Landau 2004).

\subsection{Wood density radial variation}

Several authors have shown that wood density varies significantly from pith to bark, with a difference that can reach 200 to $300 \%$ in some species (De Castro et al. 1993). This is particularly the case for temperate forests (Corylus colurna L. by Zeidler (2012)) and plantations (Eucalyptus grandis $\times$ urophylla by Baillères et al. (2005)). Radial variation in wood density is associated with competition for light (Wiemann and Williamson 1989). Early in their growth, light-demanding trees use their resources for height growth in order to reach the light at the top of the canopy quickly so that the leaves perform the photosynthesis. Once the necessary height is reached, the trees correct their structural imbalance by producing denser xylem. Our results are not in accordance with those studies, as the distance to pith did not influence wood density. One possible reason may be that temperate forests and plantations are often monospecies, and the favourable environment allows tree to grow fast. Thus, densities change significantly for each growth phase. In contrast, because of the environmental stresses conditions in the medium-altitude natural forest of Mandraka, with high overall slopes of $50 \%$ (reaching $90 \%$ in some places) and exposure to wind, the growth of trees in Mandraka is slowed. Thus, no significant trend occurs on densities for each growth phase.

\section{Conclusion}

This study is the first to investigate the factors responsible for the variability of wood properties in Madagascar. It also provides light requirements of 23 species that have never been published before. In the case of the natural forest of Mandraka, tree species and soil types have an effect on average wood density, whereas tree diameter does not. The average wood density is higher on poor ferralitic soils than on fertile lowland soils. Shade-tolerant species exhibited higher average wood density than light-demanding species. However, wood density did not show significant variation from pith to bark. Consequently, none of the factors considered have significant effects on radial variation of density.

Information on the variation in wood density is important to guide forest management activities. In addition, these results help fill the gaps in wood properties database for tree forest species in Madagascar. Knowledge of wood density can help address current issues of finding substitutes for precious Malagasy woods, such as rosewood, which are highly valued by consumers. Malagasy 
consumers prefer heavy wood (i.e., density $>0.7$ g.cm ${ }^{-3}$ ) for their furniture (Ramananantoandro et al. 2013). This study highlights four heavy woods: Dilobeia thouarsii, Anthocleista madagascariensis, Syzygium cumini and Nuxia capitata, which could be selected as alternatives to the rare precious woods. However, studies on the aesthetic, mechanical and woodworking properties of these species are needed before a complete conclusion can be drawn.

Acknowledgments The equipment used for this study was supported by TWAS (The World Academy of Sciences) and CIRAD (Centre de Coopération Internationale en Recherche Agronomique pour le Développement). The authors thank Andriambelo Radonirina Razafimahatratra (ESSA-Forêts) for his assistance with the R software, Lucienne Wilmé and Chris Birkinshaw (Missouri Botanical Garden) for providing survey data for Anjozorobe-Angavo forest corridor, Direction Générale des Eaux et Forêts staff for providing national survey data for Madagascar forest, Susan Becker for proofreading the manuscript and field staff in Mandraka site for their help in collecting wood samples.

\section{Compliance with ethical standards}

Funding The equipment used for this study was supported by TWAS (The World Academy of Sciences) and CIRAD (Centre de Coopération Internationale en Recherche Agronomique pour le Développement).

\section{References}

Baillères H, Vitrac O, Ramananantoandro T (2005) Assessment of continuous distribution of wood properties from a low number of samples: application to the variability of modulus of elasticity between trees and within a tree. Holzforschung 59:524-530. doi:10.1515 /HF.2005.087

Baker TR, Phillips OL, Malhi Y, Almeida S, Arroyo L, Di Fiore A, Killeen TJ, Laurance SG, Laurance WF, Lewis SL, Lloyd J, Monteagudo A, Neill DA, Patino S, Pitman NCA, Silva N, Martınez RV (2004) Variation in wood density determines spatial patterns in Amazonian forest biomass. Glob Change Biol 10:545562. doi:10.1111/j.1529-8817.2003.00751.x

Baltzer JL, Thomas SC (2007) Determinants of whole-plant light requirements in Bornean rain forest tree saplings. J Ecol 95:1208-1221. doi:10.1111/j.1365-2745.2007.01286.x

Chave J, Muller-Laundau HC, Baker TR, Easdale TA, Steege H, Webb CO (2006) Regional and phylogenetic variation of wood density across 2,456 neotropical tree species. Ecol Appl 16:2356-2367. doi:10.1890/1051-0761(2006)016[2356:RAPVOW]2.0.CO;2

Chave J, Coomes D, Jansen S, Lewis SL, Swenson NG, Zanne AE (2009) Towards a worldwide wood economics spectrum. Ecol Lett 12:351366. doi:10.1111/j.1461-0248.2009.01285.x

Chowdhury Q, Khan R, Mehedi AH (2013) Wood density variation in four plantation species growing in Bangladesh. J Indian Acad Wood Sci 10:32-38. doi:10.1007/s13196-013-0090-y

Coutand C, Jeronimidis G, Chanson B, Loup C (2004) Comparison of mechanical properties of tension and opposite wood in Populus. Wood Sci Technol 38:11-24. doi:10.1007/s00226-003-0194-4
De Castro F, Williamson GB, Dejesus RM (1993) Radial variation in the wood specific-gravity of Joannesia princeps: the roles of age and diameter. Biotropica 25:176-182. doi:10.2307/2389181

Ducrey M, Labbé P (1985) Etude de la régénération naturelle contrôlée en forêt tropicale humide de Guadeloupe. I Revue bibliographique, milieu naturel et élaboration d'un protocole expérimental. Ann For Sci 42:297-322. doi:10.1051/forest:19850304

Dupuy B, De Madron DL, Petruci Y (1998) Sylviculture des peuplements naturels en forêt dense humide africaine. Acquis et recommandations. Bois For Trop 257:5-22

Fukazawa K (1984) Juvenile wood of hardwoods judged by density variation. IAWA Bull 5:65-73. doi:10.1163/22941932-90000861

Goodman SM, Raselimanana AP, Wilmé L (2007) Inventaires de la faune et de la flore du couloir forestier d'Anjozorobe-Angavo. Recherche pour le développement, Série Sciences Biologiques $N^{\circ} 24$. Centre d'Information et de Documentation Scientifique et Technique, Antananarivo, Madagascar, 217 p. ISSN 1025-3467

Guilley E (2000) La densité du bois de chêne sessile (Quercus petraea Liebl.) Elaboration d'un modèle pour l'analyse des variabilités intraet interarbres. Origine et Evaluation non destructive de l'effet "arbre", Interprétation anatomique du modèle proposé. Ecole Nationale du Genie Rural des Eaux et Forêts, Nancy, France

Hall JB, Swaine MD (1981) Distribution and ecology of vascular plants in a tropical rain forest. Forest vegetation in Ghana. W. Junk, La Haye, The Netherlands, $383 \mathrm{p}$

Henry M, Besnard A, Asante WA, Eshun J, Adu-Bredu S, Valentini R, Bernoux M, Saint-Andre L (2010) Wood density, phytomass variations within and among trees, and allometric equations in a tropical rainforest of Africa. Forest Ecol Manag 260:1375-1388. doi:10.1016/j.foreco.2010.07.040

King DA, Davies SJ, Tan S, Noor NSM (2006) The role of wood density and stem support costs in the growth and mortality of tropical trees. J Ecol 94:670-680. doi:10.1111/j.1365-2745.2006.01112.x

Machado JS, Louzada JL, Santos AJA, Nunes L, Anjos O, Rodrigues J, Simões RMS, Pereira H (2014) Variation of wood density and mechanical properties of blackwood (Acacia Melanoxylon R. Br.). Mater Design 56:975-980. doi:10.1016/j.matdes.2013.12.016

McLean JP, Zhang T, Bardet S, Beauchêne J, Thibaut A, Clair B, Thibaut B (2011) The decreasing radial wood stiffness pattern of some tropical trees growing in the primary forest is reversed and increases when they are grown in a plantation. Ann For Sci 68:681-688. doi:10.1007/s13595-011-0085-z

MEF Ministère de l'Environnement et des Forêts (1996) Inventaire Ecologique Forestier National-Annexes. Madagascar

Montes CS, Hernandez RE, Beaulieu J (2007) Radial variation in wood density and correlations with growth of Calycophyllum spruceanum at an early age in the Peruvian Amazon. Wood Fiber Sci 39:377-387

Muller-Landau HC (2004) Interspecific and intersite variation in wood density of tropical trees. Biotropica 36:20-32. doi:10.1111/j.17447429.2004.tb00292.x

Nock CA, Geihofer D, Grabner M, Baker PJ, Bunyavejchewin S, Hietz P (2009) Wood density and its radial variation in six canopy tree species differing in shade-tolerance in western Thailand. Ann Bot 104: 297-306. doi:10.1093/aob/mcp118

Patino S, Lloyd J, Paiva R, Baker TR, Quesada CA, Mercado LM, Schmerler J, Schwarz M, Santos AJB, Aguilar A, Czimczik CI, Gallo J, Horna V, Hoyos EJ, Jimenez EM, Palomino W, Peacock J, Pena-Cruz A, Sarmiento C, Sota A, Turriago JD, Villanueva B, Vitzthum P, Alvarez E, Arroyo L, Baraloto C, Bonal D, Chave J, Costa ACL, Herrera R, Higuchi N, Killeen T, Leal E, Luizao F, Meir P, Monteagudo A, Neil D, Nunez-Vargas P, Penuela MC, Pitman N, Priante Filho N, Prieto A, Panfil SN, Rudas A, Salomao R, Silva N, Silveira M, deAlmeida SS, Torres-Lezama A, Vasquez-Martinez R, Vieira I, Malhi Y, Phillips OL (2009) Branch xylem density variations across Amazonia. Biogeosci 6:545-568. doi:10.5194/bg-6545-2009 
R Development Core Team (2012) R: A language and environment for statistical computing. R Foundation for Statistical Computing, Vienna, Austria. http://www.R-project.org/. Accessed April 2013

Rajaonera ML (2008) Mise en place d'un état de référence et d'un plan de suivi écologique permanent des vestiges de forêt primaire de la Station Forestière de Mandraka. Mémoire de fin d'études, Ecole Supérieure des Sciences Agronomiques, Antananarivo, Madagascar

Rajoelison LG, Randriamboavonjy JC, Razafindramanga M, Rabenilalana FM, Rakoto Ratsimba H (2007) Aménagement participatif d'un bassin versant de la Mandraka, Rapport final CDE. Antananarivo, Madagascar

Ramananantoandro T, Ramanakoto MF, Rajemison AH, Eyma F (2013) Relationship between density and aesthetic attributes of wood and preference of Malagasy consumers. Ann For Sci 70:649-658. doi:10.1007/s13595-013-0299-3

Rollet B (1984) Etudes sur une forêt d'altitude des Andes Vénézuéliennes. Bois For Trop 205:3-23

Schatz GE (2000) Endemism in the Malagasy tree flora. In: Lourenço WR, Goodman SM (eds) Diversity and endemism in Madagascar. Mémoires de la Société de Biogéographie, Paris, pp. 1-9

Sharma PD (2005) Ecology and Environment. Rastogi Publications, New Delhi, India, 640 p. ISBN 8171339050
Thibaut B, Baillères H, Chanson B, Fournier DM (1997) Plantation d'arbres à croissance rapide et qualités des produits forestiers sous les tropiques. Bois For Trop 252:49-53

Van Gelder HA, Poorter L, Sterck FJ (2006) Wood mechanics, allometry, and life-history variation in a tropical rain forest tree community. New Phytol 171:367-378. doi:10.1111/j.1469-8137.2006.01757.x

Whitmore TC (1990) Tropical rain forests. Clarendon Press, Oxford, p. 238

Wiemann MC, Williamson GB (1989) Radial gradients in the specific gravity of wood in some tropical and temperate trees. For Sci 35: 197-210

Wimmer R, Downes GM, Evans R (2002) High-resolution analysis of radial growth and wood density in Eucalyptus nitens, grown under different irrigation regimes. Ann For Sci 59:519-524. doi:10.1051 /forest:2002036

Woodcock DW, Shier AD (2003) Does canopy position affect wood specific gravity in temperate forest trees? Ann Bot 91:529-537. doi:10.1093/aob/mcg054

Zeidler A (2012) Variation of wood density in Turkish hazel (Corylus Colurna L.) grown in the Czech Republic. J For Sci 58:145-151 